\title{
HOW DOES COMMUNICATION INFLUENCE THE PERCEIVED PERFORMANCE OF MAINTENANCE SERVICES IN MULTI-STOREY PUBLIC HOUSING?
}

\author{
Nor'Aini YUSOF a,*, Shardy ABDULLAH a, Nurul 'Ulyani MOHD NAJIB a \\ a School of Housing, Building and Planning, Universiti Sains Malaysia, 11800 Penang, Malaysia
}

Received 26 October 2012; accepted 10 July 2013

\begin{abstract}
Currently, debates on the performance of maintenance services in multi-storey public housing have been matters of great concern. Previous studies have proven that a close relationship between the residents and the management team is vital to enhance the performance of maintenance services, but limited studies have been geared towards the influence of communication on the performance of maintenance services. This study aims to examine the influence of communication between the residents and the management team on the performance of the maintenance services. A survey was conducted with the residents of multi-storey public housing in Penang, Malaysia, who were selected using stratified random sampling. A descriptive analysis, Pearson product-moment correlation, and multiple regression analysis were used to analyse the data. The results show that there is a significant and positive relationship between effective communication and the residents' perceived performance of maintenance services. Two communication attributes, "satisfaction with the feedback" and "accuracy of information", are the determinants for the performance of maintenance services.
\end{abstract}

KEYWORDS: Communication effectiveness; Maintenance service performance; Resident perception; Public housing; Malaysia

\section{INTRODUCTION}

In every construction project, the quality of the end product, which is the building and its services, is commonly viewed in terms of time, cost and meeting the client's specification (Batagan, Pocovnicu 2011). Recently, building owners and residents are increasingly aware of sustainable living environments, and one of the key aspects that enables them to achieve sustainability is having a proper maintenance system so that the building they reside is in good condition (Yau, Ho 2009; Yau 2010). Building maintenance is systematic: supervised actions in the repair activity attempt to maintain or restore the building elements and facilities to an acceptable standard of building performance (Chew et al. 2004; Kangwa, Olubodun 2006) and appropriate use (El-Haram, Horner 2002). The main objectives of undergoing building maintenance are to slow down the rate of building decay; to protect building function, asset value, and usual appear-

\footnotetext{
* Corresponding author. E-mail: ynoraini@usm.my
}

ance; and to ensure a healthy living environment (Hills, Worthing 2006; Stewart et al. 2006; Yau 2011a). Generally, building maintenance can be classified into two categories: (i) corrective maintenance, which is performed after defect occurs, usually upon receiving a report from the residents, and (ii) preventive maintenance, which is performed on a regular basis and continuously at fixed intervals before a defect happens (El-Haram, Horner 2002; Siegert 2004; Li, Ni 2009). In most cases, building maintenance is performed after the defects have occurred, particularly when the residents could no longer bear the problem (Yau 2010). This form of maintenance, which is reactive in nature, has been the practice in many countries despite the fact that studies have proven that investing in a proper or systematic maintenance system results in benefits to building owners and residents (Siegert 2004; Yau, Ho 2009). According to Brackertz and Kenley (2002), Brackertz (2006), and Batagan and Pocovnicu (2011), when managing public prop- 
erties, high quality maintenance service will result in better physical performance of public facilities, which subsequently will produce better service outcomes. Similarly, in Wilhelmsson's (2008) analysis of the price differentiation of maintained and unmaintained residential buildings, the author demonstrates that well-maintained buildings fetch a $13 \%$ higher price than unmaintained buildings of the same age. Mossel and Straub's (2009) survey of tenants of social housing in the Netherlands also reveals the benefits of proper maintenance; these benefits include a sustained quality and an enhanced market value of the residential buildings. Opting for a performance-based maintenance contract, which is aimed towards meeting performance criteria set by clients, compared to the conventional competitive tendering also proved to be a cost-saving act, as it eased both indirect and direct costs (Straub 2009).

In the meantime, previous studies have shown that an effective maintenance system will only become a reality if the stakeholders play their role in the maintenance system. Involvement of the professional property manager, who has the knowledge and was trained for the maintenance work, in the maintenance system, for instance, can help to enhance the building performance in the terms of value, function and reduced shortcoming (Hastings et al. 2006). In addition, the role of residents is equally important. Although maintenance management staffs must regularly inspect the house and regularly interview the residents about their current house condition (Chew et al. 2004; Hills, Worthing 2006), to continuously keep the house in good condition and lengthen the building, residents are also expected to actively participate in the housing management, such as reporting the defect, attending meetings and participating in some maintenance activities (Hui 2005; Yau, Ho 2009; Yau 2011a). A study by Ho et al. (2006) found that a committed residents' association will lead to better building conditions. Closer ties among residents will help reduce conflict and are crucial to expedite maintenance actions (Ariff, Davies 2011). Yip (2001) found that in Hong Kong public housing, active participation by the residents in the maintenance process has led towards fewer corrective maintenance projects and higher resident satisfaction. In this regard, Hui (2005) coined the term "partnership mode" to explain the active involvement of the residents, building management and maintenance professionals in carrying out the overall duties of building management. In short, to accomplish building maintenance objectives as mentioned above, it involves evidence of interaction between the residents, management team and maintenance professionals.

The above discussion proved that to develop an effective maintenance system, the residents and the management team should work together. Thus, it is essential to have good and distinct twoway communication between these individuals to ensure any needed repair or maintenance work can be done quickly and to the satisfaction of the residents.

There is a growing body of literature about building maintenance that focuses on maintenance service performance. Lai, Pang (2010) evaluated contractors' performance in relation to maintenance work from the viewpoints of house owner representatives and tenants and revealed that complaints abound with regards to promptness of maintenance services and lack of resources to provide the promised services. Lujanen (2010) analysed maintenance service performance in ten European countries and discovered that the main reason for poor maintenance in the common area of owner-occupied residential buildings is a flaw in the legislation with regard to the management of the common area. The vagueness in the legislation means that participation in maintenance work is only on a voluntary basis, which led to poor maintenance. Yau (2011a) and Yau (2013) confirmed that private housing residents in Hong Kong are generally unwilling to participate in the residents' meetings and maintenance activities, and the residents would only participate in the maintenance activities if they were dissatisfied with the performance of the housing management. Yau (2011b) further introduced a collective interest model (CIM) to explain owner-resident behaviour in monitoring the work of property management agents and managing the common area of multiowner housing schemes, within the context where such involvement is voluntary in nature.

However, only few studies provide insight into how the interrelationship between the management team and the residents can influence the current performance of maintenance services in public housing. Lujanen (2010) suggested that the establishment of residents' associations should expedite decision making and effective collection of service charges to support major repair works. Mossel and Straub (2009) surveyed tenants in Netherland's social housing and discovered that it is necessary to customise maintenance services according the different needs of the tenants to achieve a high level of tenant satisfaction and, subsequently, an 
improved maintenance performance. The closest study in Malaysia that focused on the relationship between the main players in multi-storey housing is by Ariff and Davies (2011), who analysed the impact of homeownership on owner-residents satisfaction with their relationships with other players in the low-cost housing in Selangor, Malaysia, but their study did not focus on the performance of the maintenance services. Although the abovementioned studies shed some light on resident and maintenance team relationships, these studies provide little evidence on how the key players in the maintenance system, particularly the residents and management team, communicate or on how the quality of the information they receive and provide influences the performance of the maintenance services and, thus, the condition of the building of residence.

The present study aims to fill in the gap and determine the effect of communication on the performance of maintenance services in multi-storey residential buildings. Consequently, the main question for the present study is, "does communication between residents and the maintenance management team influence the perceived performance of maintenance services in public housing?" This study provides insights into the impact of communication on improving the performance of maintenance services in multi-storey public housing. Specifically, the study aims to identify key communication attributes on which the management of public housing needs to focus in order to enhance the performance of maintenance service. The information will serve as a guide to those involved in the management of public housing, highlighting communication attributes that are effective when dealing with defect reporting and informing corrective actions to the residents, which subsequently guarantees successful maintenance service delivery. The results will also provide useful reference for the local authorities who are responsible for the overall maintenance management system of the public housing, laying out which communication practices are vital so that they can align their service strategy with the residents' expectations.

\section{MAINTENANCE SERVICE PERFORMANCE AND EFFECTIVE COMMUNICATION}

Maintenance service performance is defined by a specific report of measuring performance concerning effectiveness, efficiency or productivity of certain operations or planning in a given period
(Pintelon, Puyvelde 1997). In the case of building maintenance, maintenance service performance is concerned with measuring the performance of technical and managerial actions so that the building remains at an acceptable standard to carry out its function (Ali et al. 2010). Traditional performance measurement, which includes meeting the time, cost and quality goals of a project, is argued to be insufficient in providing a holistic performance evaluation (Kelly 2003; Lai, Pang 2010). The global expansion of the service sector has resulted in a focus on the end product and the delivering process of the service (Siu et al. 2001). In tandem with this development, performance measurement is now gearing towards achieving customer satisfaction and quality service delivery (Kelly 2003; Perng et al. 2007; Anderson, Mansi 2009).

It is not surprising that there are a growing number of studies evaluating maintenance service performance based on residents' perception of the maintenance work and service delivery. Using one service quality model, Siu et al. (2001) investigated the performance of maintenance of mechanical and engineering services from the users' perspective and revealed that the performance was below expectations. They proposed that measurements should be based on customer perception to overcome weaknesses and provide opportunities for improvement in the service delivery. A study by Kangwa and Olubodun (2007) in Northwest England also focused on the recipients of the service, the residents, and found that they are dissatisfied with the quality of maintenance work. This finding correlates with the residents' previous knowledge about defects and, subsequently, their high expectation of maintenance outcome. Jiboye (2011) studied the perceptions of homeowners of public housing in Nigeria who lived in deplorable houses and inadequate infrastructure facilities and found that these homeowners rate the performance of their house maintenance as low. Mossel and Jansen (2010) surveyed 6000 residents of social housing in the Netherlands about the priorities of maintenance services that are carried out by housing associations. The residents ranked heating and water systems, hinges and locks of windows, and external doors as the most important maintenance priorities. Mossel and Jansen's (2010) study, however, did not evaluate the performance of the maintenance services. In short, past studies have indicated that the performance indicator for the maintenance services is best based on the perceptions of the users of the service, which in the case of multi-storey housing, is the residents. 
How is maintenance service performance measured? As mentioned above, because of the need to achieve customer satisfaction and quality service delivery, the measurement of maintenance service performance includes both the quality of the outcome and the quality of the delivery of such work to the residents (Low, Peh 1996; Yasamis et al. 2002; Lai, Pang 2010). This definition aligns with the "perceived service quality model" put forward by Gronroos and Ojasalo (2004), who suggested that the quality of the output is evident to a certain extent in the process and in the outcome of the process. Therefore, performance measurement should consider the interrelationships between the service provider, which is the management team, and the residents who received the service (Lai, Pang 2010). The measurement should include both the outcome of the maintenance work and the delivery process of the maintenance service (Lai, Pang 2010). This is in tandem with the suggestion made by Williams et al. (1999) regarding performance measurement, which focuses on the quality of the service offered by the provider to the receiver, to facilitate service improvement.

Past studies have noted several variables that are regarded as performance indicators of maintenance management. Hui (2005) and Straub (2009) assert that a committed maintenance team, which can be seen through well-disciplined staff and a high level of professionalism, is regarded as a high performance of the maintenance services and can even cut costs. Good attitudes of the maintenance professionals, such as assuring the quality of the work is up to residents' standard requirements, is also considered a good maintenance service performance indicator (Stewart et al. 2006; Lai, Pang 2010). Ensuring that the services the maintenance team delivered are worth the money paid is considered one of the maintenance service performance indicators (Hui 2005). Friendliness towards residents is also part of maintenance performance (Hui 2005; Mossel, Jansen 2010). In addition, the organisational structure and the resources of the maintenance team are considered part of maintenance service performance. Appropriate work structures that allow easy contact for defect reporting is vital for better maintenance performance (Lam 2008). Resources that the maintenance service providers have are also important. Kangwa and Olubodun (2007) stressed that capability and availability of the equipment and materials related to maintenance work, including the work price relative to current and standard rates and work compliance to health and safety requirements, can boost the performance of maintenance services carried out by the maintenance professionals.

In the meantime, it was observed that the good performance of maintenance services not only depends on the maintenance management staff, but it also depends on the residents' awareness and skill-knowledge, especially in the identification of the severity of house defects and the root causes of the defects (Kangwa, Olubodun 2003; Ali et al. 2010). This awareness and knowledge about defects is important because when the residents are unable to remedy the defects themselves, they have to report the defects immediately and clearly to the responsible maintenance management staff member so that the maintenance professionals can easily take action in favour of the residents' request (Stewart et al. 2006). This correlation suggests the need for effective communication between the residents and the maintenance team.

The importance of communication in maintenance service systems can be traced from the work of Octavia Hill, who emphasised a good rapport between the residents and housing managers as a tool for quality housekeeping (Clapham et al. 2000). Octavia Hill's work provides an alternative approach of housing management, which focuses on managing the people rather than the property (Casey 2008). The two-way communication encompasses the main players actively involved in formal progress meetings as well as informal communication to allow exchange of ideas and timely feedback (Hui 2005).

Previous studies have acknowledged three criteria as important for effective communication: accuracy of the information, responsiveness of the staff and satisfaction with the feedback. In terms of "accuracy of the information", the information that the service provider provides should be able to make the users aware of their own decision or actions (Oyedele, Tham 2007). In the case of multistorey housing, this factor involves making sure the information received from the management or maintenance workers is clear and as accurate as possible to help the residents understand the basic knowledge of maintenance and undertake the necessary actions (Hui 2005). In this regard, Kangwa and Olubodun $(2003,2006)$ argue that residents must at least have a simple knowledge of the root causes of the defects so that they can always be aware of the severity of house defects and can provide the necessary feedback to the management team, who can then share this information with the maintenance staff. It is also important that feedback from the residents can reach the main- 
tenance staff in a timely manner (Hui 2005). As observed by El-Haram and Horner (2002), delayed reports or a complete failure to report defects by the residents will cause maintenance costs to increase. Thus, to ensure information can be transferred effectively, a well-organised and systematic communication plan that links the residents, management team and maintenance staff must be in place in the management system (Hamzah et al. 2011). In certain cases, residents must have at least a basic knowledge of building maintenance, perhaps through the sharing of experiences, in order to provide valuable information that will assist the maintenance staff in correctly identifying the problem and carrying out the necessary repair work (Kangwa, Olubodun 2003, 2006). Meanwhile, residents cannot simply rely on the maintenance team or assume that repairs to their house are wholly the responsibility of the maintenance professionals (Christudason 2007). Having some of the basic maintenance knowledge through accurate information sharing or sharing of experience between the maintenance team and the residents is extremely valuable for allowing the residents to do minor repair work in a workman-like manner. Hills and Worthing (2006) and Yau (2011a) assert that skilled-knowledge about maintenance and repair work would foster confidence in the residents and subsequently motivate the residents to undertake preventive maintenance themselves. In line with this idea, frequent undertaking of preventive maintenance through day-to-day activities such as cleaning, clearing gutters, painting or fixing minor repairs would prolong the life of building elements (Hills, Worthing 2006; Kangwa, Olubodun 2007). In short, we postulate that the accuracy of information received by the residents would significantly influence the performance of the maintenance services.

In general, the responsiveness of the management team involves taking prompt and accurate actions in response to residents' reports or complaints (Hui 2005; Yau 2011a). Responsiveness is also concerned with responding to residents' queries, the keenness of the management staff to assist the residents, and the attentiveness of the management team to inform the residents when the repair work will be carried out (Hui 2005). A study by Lee and Wordsworth (2001) revealed a direct relationship between the timely response to the defects report and the rate of building deterioration. They also suggested the need to have a timely response in the management system to minimise maintenance costs and ensure good building performance. Similarly, Narayan (2003) found that delayed or completely failed attempts to carry out maintenance work after defects were detected would worsen the defects. A recent study by Ali et al. (2010) revealed that low-cost housing residents in Malaysia rank a delay in doing the repair work or an unattended defect as the third most vital factor in maintenance performance. Therefore, we postulate that the responsiveness of the management team would significantly influence the performance of maintenance services.

Little evidence is available on whether residents' satisfaction with the feedback received from the management team will affect residents' perception of the performance of the maintenance services. Communication may be formal or informal, may be delivered through written or verbal forms and is associated with one's emotion and thus the level of trust between the parties involved (Turner, Muller 2004). Generally, residents have insufficient knowledge about maintenance or repair works, but they still need to be assured that their building is properly maintained and in good condition (Hills, Worthing 2006; Yau 2011a). According to Graham (2003), there are three pieces of information the clients expect to receive from their agent through communication: first, the outcome of the work and assurance that the appropriate action has been taken; second, the performance in terms of quality, cost and time; and third, information about the behaviour of the agent and whether he is dependable. Turner and Muller (2004) revealed that the motivation to inquire for information arises from dissatisfaction about performance. Similarly, Yau (2011a) suggested that if the residents are more concerned about the housing performance and are dissatisfied with the housing condition, they would be more likely to be involved in maintaining the building. Therefore, a high desire for communication among the residents would lead towards better performance compared to a low desire to communicate (Turner, Muller 2004). Accordingly, we postulate that the residents' satisfaction with the information received from the management team has a significant influence on the performance of maintenance services.

From the above discussion, we postulate that there is a positive correlation between the perceived maintenance service performance and effective communication. Further we postulate that:

$\mathrm{H} 1$ : Accuracy of information is significant for maintenance services performance;

$\mathrm{H} 2$ : Responsiveness of the management team is significant for maintenance service performance; 


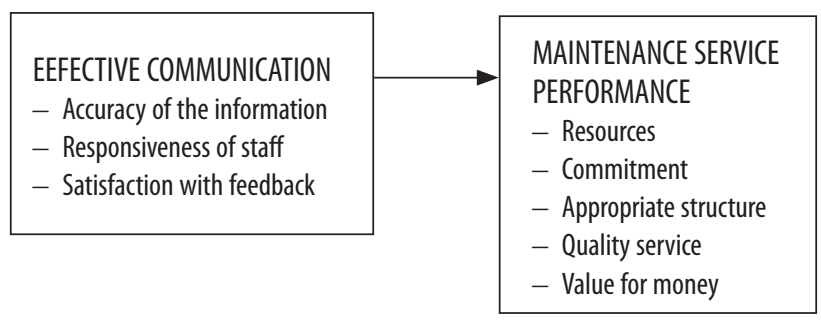

Fig. 1. Framework of study

H3: Residents' satisfaction with the feedback given is significant for maintenance service performance.

\section{MATERIALS AND METHODS}

\subsection{Selection of respondents}

The population of this study consists of residents who reside in the public housing in the state of Penang, Malaysia. The state of Penang was chosen for the case study because of it is one of the most developed states in Malaysia and ranks second in terms of the number of multi-storey public housing, after Klang Valley, which has been the focus of most housing maintenance studies in Malaysia (for example, Ali et al. 2010; Che Ani et al. 2010; Ariff, Davies 2011). A list of 3947 units of multi-storey public housing was obtained from the two local authorities in Penang, namely, Majlis Perbandaran Pulau Pinang and Majlis Perbandaran Seberang Perai, based on completed public housing units within the last 10 years. A stratified random sampling was employed to select the 840 respondents with a $95 \%$ confidence level and margin of error of plus-minus 3 . The targeted respondents are residents who are registered with the local authorities. For this reason, stratified random sampling was used to ensure responses are received from registered residents only and not their relatives.

Several steps were taken to reduce the nonresponse issue that were based on suggestions of past studies (see Groves et al. 1992; Ryu et al. 2005; Zagorsky, Rhoton 2008; Ali 2009). First, the survey was administered face to face by trained interviewers to the head of the households, and the length of the survey was made simple so that it took less than 10 minutes to complete. Second, the respondents were given a ballpoint pen with the researchers' institutional logo on it as an incentive. Third, follow-up visits were arranged for non-responses or respondents who were away. Fourth, as much as possible, interviewers were selected that had similar characteristics to the respondents, i.e., same race, gender and spoken language. Fifth, we established contact with the building manager and residents' association to inform them of our study and to explain the benefits they would gain from the study. We also informed the building manager and the chairperson of the residents' association of the date and time for the survey so that our interviewers were not mistaken as sale persons or charity contributors. We received 398 useable answers, which is a response rate of $47.38 \%$. Our response rate of $47.38 \%$ is acceptable because it is higher than that of Ariff and Davies (2011) (26.5\%) and similar to that of Siu et al. (2001) (42\%), who conducted their studies with a similar group of people, i.e., users of maintenance services.

\subsection{Questionnaire form and data analysis}

To probe and assess the perceived satisfaction level with the maintenance service performance of residents in public housing, the respondents were asked to opine their feeling of satisfaction with various observed maintenance service responses directly. The questionnaire included questions about the residents' profile, their level of effective communication, and the performance of maintenance services. A four-point scale was used ranging from $1=$ very poor or very dissatisfied to $4=$ very good or very satisfied. The reason for using a 4 point scale is to avoid a neutral answer which could lead towards bias; instead we wish to force the respondents to show their preference. We follow Garland's (1991) suggestion of excluding the neutral answer so as to avoid "interviewer bias"; a term used to describe a situation where a respondent is reluctant to give an unacceptable answer and tends toward no opinion (a neither....nor answer) to please the interviewer. This stance is supported by Krosnick and Fabrigar (1997) who argue that a neutral answer is an easy choice for respondents who feel burdened and put little effort into answering but, at the same, want to appear to be answering responsibly.

The data were analysed using descriptive analysis, a correlation test, and regression analysis with the help of the SPSS software. Before performing the analyses, the reliability test was conducted for all indicators in the constructs "effective communication" and "maintenance services performance". This step was used to verify the internal consistency of the items used, so that if the test is carried out by different people, the scale will behave in a similar manner. The results show that Cronbach's alpha values for the two constructs are 0.577 and 0.688 ; 
Table 1. Profile of the respondents

\begin{tabular}{|c|c|c|c|}
\hline & & Frequency & $\%$ \\
\hline \multicolumn{4}{|l|}{ SEX } \\
\hline \multirow[t]{3}{*}{ Valid } & male & 177 & 44.5 \\
\hline & female & 221 & 55.5 \\
\hline & Total & 398 & 100.0 \\
\hline \multicolumn{4}{|l|}{ AGE } \\
\hline \multirow[t]{6}{*}{ Valid } & $20-30$ & 9 & 2.3 \\
\hline & $31-40$ & 37 & 9.3 \\
\hline & $41-50$ & 263 & 66.1 \\
\hline & $51-60$ & 64 & 16.1 \\
\hline & $>60$ & 25 & 6.3 \\
\hline & Total & 398 & 100.0 \\
\hline \multicolumn{4}{|c|}{ OCCUPATION } \\
\hline \multirow[t]{6}{*}{ Valid } & $\begin{array}{l}\text { government } \\
\text { servant }\end{array}$ & 25 & 6.3 \\
\hline & self-employed & 94 & 23.6 \\
\hline & private & 190 & 47.7 \\
\hline & housewife & 55 & 13.8 \\
\hline & other & 34 & 8.5 \\
\hline & Total & 398 & 100.0 \\
\hline \multicolumn{4}{|c|}{ INCOME } \\
\hline \multirow[t]{4}{*}{ Valid } & $<$ RM 1500 & 22 & 5.5 \\
\hline & RM 1500-2500 & 272 & 68.3 \\
\hline & RM 2500-5000 & 104 & 26.1 \\
\hline & Total & 398 & 100.0 \\
\hline \multicolumn{4}{|c|}{ LENGTH OF STAY } \\
\hline \multirow[t]{4}{*}{ Valid } & $<1$ year & 6 & 1.5 \\
\hline & $1-5$ year & 55 & 13.8 \\
\hline & $6-10$ year & 337 & 84.7 \\
\hline & Total & 398 & 100.0 \\
\hline \multicolumn{4}{|c|}{ COMPLAINT-INSPECTION GAP } \\
\hline \multirow[t]{4}{*}{ Valid } & 1 days & 226 & 56.8 \\
\hline & 2 days & 127 & 31.9 \\
\hline & 3 days & 45 & 11.3 \\
\hline & Total & 398 & 100.0 \\
\hline
\end{tabular}

these are above the minimum value of 0.5 considered acceptable by Van de Ven and Ferry (1979), Altman (1991), Bowling (2002) and more recently Streiner and Norman (2008). All items therefore were retained for the subsequent analyses.

\section{RESULTS}

\subsection{Respondents profile}

Table 1 illustrates the respondent profile. It indicates $55.5 \%$ of the respondents were female, $66 \%$ were age 41 to 50 years, nearly $48 \%$ of the respondents worked in a private sector while approximately $24 \%$ were self-employed with a majority of the households at an income of EUR 378-630.60 (MYR 1500-2500). Nearly $85 \%$ of the residents had been in the housing scheme for 6 to 10 years. A total of $56.8 \%$ of the respondents revealed that the average number of days that passed between the housing complaint and an inspection of the unit was 1 day, and $32 \%$ reported the gap as 2 days.

\subsection{Performance of maintenance services}

A descriptive analysis was performed to calculate the residents' perception of the performance of maintenance services provided by the maintenance management. Table 2 shows the mean scores and standard deviation (SD) for the items of "maintenance services performance". A computed overall average mean score of 2.85 suggests that the residents were generally satisfied with the performance of the provided maintenance services. As tabulated in Table 2, the residents were particularly satisfied in these areas "maintenance management has the resources to do a good job" $(\mathrm{M}=3.02, \mathrm{SD}=0.333)$, "maintenance management cares about its residents/tenants" ( $\mathrm{M}=2.92, \mathrm{SD}=$ $0.268)$, "maintenance management provides good services" $(\mathrm{M}=2.87, \mathrm{SD}=0.332)$, "overall quality of

Table 2. Performance of maintenance services from residents' perception

\begin{tabular}{lll}
\hline Provided maintenance services & Mean & Std. deviation \\
\hline Maintenance management has the resources to do a good job & 3.02 & 0.333 \\
Maintenance management is committed to their job & 2.92 & 0.268 \\
Maintenance management provides a good services & 2.87 & 0.332 \\
Overall quality of services by maintenance management & 2.84 & 0.417 \\
Maintenance management is easy to contact & 2.82 & 0.475 \\
Maintenance management keeps residents informed & 2.76 & 0.470 \\
Maintenance management provides good value for money & 2.71 & 0.455 \\
Maintenance service performance & 2.85 & \\
\hline
\end{tabular}


services by maintenance management" $(\mathrm{M}=2.84$, $\mathrm{SD}=0.417)$, and "maintenance management is easy to contact” $(\mathrm{M}=2.82, \mathrm{SD}=0.475)$.

\subsection{Effective communication}

Three main attributes were used to measure effective communication between the residents and the management team: the accuracy of information, the responsiveness of the management team and the residents' satisfaction from the feedback received. The accuracy of the information received from the management team as an attribute consists of the clarity of information that enables the residents to detect defects, thus creating awareness among the residents for timely reporting and empowering residents to be confident in carrying out minor repairs or preventive maintenance. The responsiveness of the management team is conceptualised by staff taking prompt actions, staff taking accurate actions, staff eagerly assisting the residents, staff responding to residents' queries and staff informing the residents when the repair work would be carried out. Residents' satisfaction with the feedback received is conceptualised in relation to the outcome of the work, the action that has been taken and the performance of the maintenance work. A descriptive analysis was performed on the communication attributes, and the result is shown in Table 3. In general, the residents consider their communication with the management staff to be good with an overall mean score of 2.76 . The highest score of the communication attributes was on the "accuracy of information received from the maintenance management" $(\mathrm{M}=2.83, \mathrm{SD}=$ 0.417), followed by "satisfaction with the feedback"

Table 3. Effective communication

\begin{tabular}{lll}
\hline Communication attributes & Mean & Std. deviation \\
\hline $\begin{array}{l}\text { Accuracy of information } \\
\text { Responsiveness of management }\end{array}$ & 2.83 & 0.417 \\
team & 2.71 & 0.674 \\
$\begin{array}{l}\text { Satisfaction with the feedback } \\
\begin{array}{l}\text { Residents-management team } \\
\text { communication }\end{array}\end{array}$ & 2.75 & 0.480 \\
\hline
\end{tabular}

$(\mathrm{M}=2.75, \mathrm{SD}=0.48)$ and "responsiveness of the management team" $(\mathrm{M}=2.71, \mathrm{SD}=0.674)$.

\subsection{Correlation between effective communication and maintenance services performance}

A Pearson product-moment correlation test was subsequently performed to investigate the relationship between effective communication and the perceived maintenance services performance. Table 4 signifies the results of the correlation test. From the results presented in Table 4, the Pearson correlation value $(\mathrm{r})$, which measures the strength and the direction of a linear relationship between effective communication and the maintenance service performance, revealed that the correlation between these two variables is 0.594 . This relationship is significant at $\mathrm{p}<0.01$, and the strength of the relationship is strong according to Pallant (2010). This result provides statistical evidence that effective communication is positively correlated with maintenance service performance. Hence, it can be said that if there is effective communication, it is very likely that the residents' will have more positive perceptions of the performance of maintenance services.

\subsection{Communication attributes which predict the performance of maintenance services}

An analysis of multiple regressions was then performed to identify which communication attributes may predict a significant unique contribution to explain residents' perception on the performance of maintenance services. Prior to the multiple regression analysis, multicollinearity of the variables was checked to ensure that i) the independent variables have at least some relationship with the dependent variable and ii) the correlation between each of independent variables is not too high. Table 5 tabulates the correlation matrix of the variables. The correlation results signified that the independent variables of this study (accuracy of information; responsiveness of management; and

Table 4. Correlation between communication and performance of maintenance services

\begin{tabular}{llll}
\hline & & Communication attributes & Maintenance performance \\
\hline Communication attributes & Pearson Correlation & 1 & $0.594^{* *}$ \\
& Sig. (2-tailed) & & 0.000 \\
& $\mathrm{~N}$ & 398 & 398 \\
Maintenance performance & Pearson Correlation & $0.594^{* *}$ & 1 \\
& Sig. (2-tailed) & 0.000 & 398 \\
\hline
\end{tabular}

Note: ${ }^{* *}$ Correlation is significant at the 0.01 level (2-tailed). 
Table 5. Correlation matrix

\begin{tabular}{llllll}
\hline & & $\begin{array}{l}\text { Maintenance } \\
\text { performance }\end{array}$ & $\begin{array}{l}\text { Accuracy of } \\
\text { information }\end{array}$ & $\begin{array}{l}\text { Responsiveness of } \\
\text { management }\end{array}$ & $\begin{array}{l}\text { Satisfaction } \\
\text { with feedback }\end{array}$ \\
\hline $\mathrm{r} \quad$ & Maintenance performance & 1.000 & 0.450 & 0.318 & 0.627 \\
& Accuracy of information & & 1.000 & 0.029 & 0.476 \\
Responsiveness of management & & & 1.000 & 0.543 \\
Satisfaction with feedback & & & 1.000 \\
\hline
\end{tabular}

satisfaction with feedback) correlate substantially with the dependent variable (maintenance service performance), with $\mathrm{r}$ values of $0.450,0.318$, and 0.627 respectively. All exceed 0.3 as preferred by Pallant (2010). Furthermore, the independent variables are not highly correlated with each other, with $\mathrm{r}$ values of $0.029,0.476$, and 0.543 ; which are less than 0.7 as suggested by Pallant (2010). Thus, the results of this correlation matrix indicated that all the variables should be retained for further regression analysis.

Table 6 presents the results of the regression model. The regression analysis showed that the amount of variance explained by variables in our model was $42.3 \%\left(R^{2}=0.423, \mathrm{df}=3, F=96.39\right.$, $p<0.01$ ), which, according to Pallant (2010), is respectable and significant.

Two attributes, "satisfaction with the feedback" and "accuracy of information", are identified as making a significant unique contribution to the residents' perceived performance of maintenance services with a $\mathrm{p}$ value less than or equal to 0.05 . Therefore, "satisfaction with the feedback" and "accuracy of information" are considered to be the predictors for maintenance service performance. In addition, the results show that the highest beta coefficient score was "satisfaction with the feedback" (with b values was significant at 0.510 ) followed by "accuracy of information" (with b value was significant at 0.206 ). The results indicate that for every $1 \%$ increase in level of residents' satisfaction with the feedback received, there is a $51 \%$ increase in maintenance service performance. Similarly, for every $1 \%$ increase in accuracy of information from the maintenance team, there is a $20.6 \%$ increase in maintenance service performance. Therefore, the

Table 6. Regression model

\begin{tabular}{lll}
\hline Variables & Beta & Sig. \\
\hline Accuracy of information & 0.206 & 0.000 \\
Responsiveness of management team & 0.035 & 0.462 \\
Satisfaction with the feedback & 0.510 & 0.000 \\
\hline
\end{tabular}

Note: $R=0.651, R^{2}=0.423, \mathrm{df}=3, F=96.39, p=0.000$. higher the level of satisfaction with the feedback received and the more accurate the information received from the management team, the higher the performance of maintenance services from the residents' perspective. In other words, these two communication attributes significantly impact residents' perception of maintenance services performance. The two communication attributes are the predictors for maintenance service performance, which should be the focus for future improvement in the maintenance system.

Meanwhile, residents identified "responsiveness of management team" as not significant to maintenance service performance, with a $p$ value of 0.462 and $a b$ value of 0.035 , indicating that this attribute is not a determinant of maintenance service performance.

\section{DISCUSSION}

The present study examined the influence of communication on the perception of maintenance service performance. This study found that, in general, there was a significant and positive relationship between communication effectiveness and the perceived maintenance services performance. The increase of communication effectiveness will inevitably cause an increase in maintenance service performance. In other words, it implied that when the maintenance management has effectively communicated the maintenance works that they have conducted to the residents, there is a better perception of maintenance service performance. The results further explained the findings of Stewart et al. (2006) and Lai and Pang (2010) about the important role of the attitude of the management team in determining the performance of the maintenance services. Specifically, the results note the importance of effective communication between the residents and the management team to ensure quality maintenance service. The results provide empirical support for the suggestion of Ali et al. (2010) that a good relationship between residents and the management team is vital to ensure resi- 
dents pay the maintenance charge, to avoid outstanding charges, a factor they rank as the highest in impacting maintenance service performance.

"Satisfaction with the feedback" and "accuracy of information" were found to be the predictors of the performance of maintenance services at Penang's public housing. The results support what we postulated earlier that resident satisfaction from the feedback received from the management team and the accuracy of the information the resident received were significant to the performance of maintenance services. Specifically, satisfaction with feedback with regard to the outcome of the maintenance work, to the action that has been taken in response to the residents' report or complaint and to the performance of the maintenance work are dominants to predict maintenance service performance. Subsequently, strong accuracy of information, which enables residents to detect defects, helps to create awareness among the residents for timely reporting, increases the residents' confidence in carrying out minor repair or preventive maintenance, and also helps predict the performance of maintenance services.

The above results support the outcome of Oyedele and Tham (2007) and Hui (2005) regarding the importance of accurate information. It also adds new insight to our understanding of the role of resident satisfaction on feedback received from the management team in determining residents' perceived performance of maintenance services and strengthens the general view that good attitudes and good behaviour of the maintenance professionals are vital for the success of maintenance services, as noted by Stewart et al. (2006) and Lai and Pang (2010). This new insight complements what is currently understood about the importance of client satisfaction and the need for client orientation or focus in service delivery, as observed by Gruis et al. (2005), Mossel and Straub (2009).

Meanwhile, quite surprisingly, our study revealed that the responsiveness of the management team is not significant to maintenance service performance. One possible reason for this result that was revealed in our survey is that the management team took between 1 and 2 days to respond to residents' complaints, which is considered acceptable by the residents. In other words, the responsiveness of the management team is not a problem in the public housing schemes covered by our study. As such, our result does not support what other researchers, such as Lee and Wordsworth (2001), Narayan (2003) and Ali et al. (2010), have found about the problem of delays in carrying out main- tenance work in the housing schemes within their studies. Thus, they stressed the importance of a timely response for the performance of maintenance service.

\section{CONCLUSIONS}

This study sought to examine the relationship between communication and maintenance service performance in multi-storey public housing in Penang, Malaysia. It aimed to identify communication attributes that significantly influence the performance of maintenance services. Knowing which communication attributes are important to maintenance service performance provides the management team with a guide for determining priorities with regard to maintenance strategy. This study suggests that to improve the current situation of public housing maintenance management, suitable mechanisms for effective communication focusing on resident satisfaction about the feedback that fulfils their expectation and ensures accuracy in information should be planned. For example, improving the relationship among the main players in maintenance through active resident participation in building management, such as taking part in identifying defects and making decisions about the implementation of repairs (Yip 2001; Hui 2005), selection of qualified and competent maintenance contractors who have good relationships with the management committee and are able to understand the needs and expectation of residents in that particular housing scheme (Hui 2005; Hastings et al. 2006), similar priority preference with regards to maintenance work between the residents and management team (Oladapo 2006) and customised maintenance services (Mossel, Jansen 2010), would improve the residents' satisfaction and foster effective communication. An establishment of systematic communication (Hamzah et al. 2011) that links the residents, management team and maintenance contractor to ensure the information received is clear and accurate (Hui 2005) and able to increase the residents' awareness about the importance of building maintenance (El-Haram, Horner 2002; Kangwa, Olubodun 2003; Ali et al. 2010) and to help the residents become aware of their actions or inactions when detecting problems (Oyedele, Tham 2007; Oladapo 2006) would ensure the accuracy of the information and result in effective communication. These findings provide valuable insight into the maintenance management corporation in managing the maintenance work of public housing. In addition, the findings can be used to develop a 
proper maintenance management model which will facilitate the achievement of sustainability goals in the management of public housing.

As previously mentioned, this study only focuses on the effect of communication on the performance of maintenance services. The coefficient of determination, or $R^{2}$, is 0.423 , which means that the model applied in the present study explained $42.3 \%$ of the total variation in the linear relationship between maintenance service performance and effective communication. The other $57.7 \%$ of the total remains unexplained. In addition to communication, other factors such as the residents' living condition, the residents' level of affordability, the residents' knowledge about defects, the residents' expectations, and the regulations and standards of maintenance work have been highlighted by previous studies as factors that influence maintenance service performance (Zavadskas, Vilutienè 2006; ElHaram, Horner 2002; Kangwa, Olubodun 2007). Studies that consider these factors will deepen our knowledge of what influences maintenance service performance.

The present study also did not take into account the moderating effect of residents' characteristics that may signify the relationship between communication and maintenance services performance. For instance, Ariff and Davies (2011) have noted the influence of household size, duration of stay and resident participation on residents' satisfaction with the stakeholders' relationships. Jiboye (2011) claimed that the adequacy of the infrastructure facility would affect the residents' perception about their housing maintenance service performance. Future studies that focus on the moderating effect of residents' characteristics and available building facilities will add value to our understanding of the factors that contribute to higher maintenance service performance.

\section{ACKNOWLEDGEMENTS}

This research was commissioned and funded by Universiti Sains Malaysia through its Research University Grant.

\section{REFERENCES}

Ali, A. S. 2009. Cost decision making in building maintenance practice in Malaysia, Journal of Facilities Management 7(4): 298-306. http://dx.doi. org/10.1108/14725960910990044

Ali, A. S.; Kamaruzzaman, S. N.; Sulaiman, R.; Peng, Y. C. 2010. Factors affecting housing maintenance cost in Malaysia, Journal of Fa- cilities Management 8(4): 285-298. http://dx.doi. org/10.1108/14725961011078990

Altman, D. G. 1991. Practical statistics for medical research. London, UK: Chapman \& Hall.

Anderson, E. W.; Mansi, S. A. 2009. Does customer satisfaction matter to investors? Findings from the bond market, Journal of Marketing Research 46(5): 703-714. http://dx.doi.org/10.1509/jmkr.46.5.703

Ariff, N. R. M.; Davies, H. 2011. Multi-owner lowcost housing management in Malaysia: effects of owner-occupant characteristics and occupancy rates, International Journal of Housing Markets and Analysis 4(3): 268-289. http://dx.doi. org/10.1108/17538271111153031

Batagan, L.; Pocovnicu, A. 2011. Online services management support for an intelligent locality, Theoretical and Applied Economics XVIII 7(560): 19-30.

Bowling, A. 2002. Research methods in health: investigating health and health services. 2 ed. Buckingham: Open University Press.

Brackertz, N. 2006. Relating physical and service performance in local government community facilities, Facilities 24(7/8): 280-291. http://dx.doi. org/10.1108/02632770610666134

Brackertz, N.; Kenley, R. 2002. A service delivery approach to measuring facility performance in local government, Facilities 20(3/4): 127-135. http://dx.doi. org/10.1108/02632770210423885

Casey, R. 2008. On becoming a social housing manager: work identities in an 'invisible' occupation, Housing Studies 23(5): 761-780. http://dx.doi. org/10.1080/02673030802254556

Che Ani, A. I.; Tawil, N. M.; Sairi, A.; Abdullah, N. A. G.; Tahir, M. M.; Surat, M. 2010. Facility management indicators for high-rise residential property in Malaysia. WSEAS Transactions on Environment and Development 6(4): 255-264.

Chew, M. Y.; Tan, S. S.; Kang, K. H. 2004. Building maintainability - review of state of the art, Journal of Architectural Engineering 10(3): 80-87. http:// dx.doi.org/10.1061/(ASCE)1076-0431(2004)10:3(80)

Christudason, A. 2007. Defects in common property of strata developments in Singapore: representative actions against developers, Structural Survey 25(3/4): 306-318. http://dx.doi. org/10.1108/02630800710772872

Clapham, D.; Franklin, B.; Saugères, L. 2000. Housing management: the social construction of an occupational role, Housing, Theory and Society 17(2): 6882. http://dx.doi.org/10.1080/140360900457740

El-Haram, M. A.; Horner, M. W. 2002. Factors affecting housing maintenance cost, Journal of Quality in Maintenance Engineering 8(2): 115-123. http:// dx.doi.org/10.1108/13552510210430008

Garland, R. 1991. The mid-point on a rating scale: is it desirable?, Marketing Bulletin 2(Research Note 3): 66-70.

Graham, R. G. 2003. Managing conflict, persuasion and negotiation, in Turner, J. R. (Ed.). People in project management. Gower: Aldershott.

Gronroos, C.; Ojasalo, K. 2004. Service productivity: towards a conceptualization of the transformation 
of inputs into economic results in services, Journal of Business Research 57(4): 414-423. http://dx.doi. org/10.1016/S0148-2963(02)00275-8

Groves, R. M.; Cialdini, R. B.; Couper, M. P. 1992. Understanding the decision to participate in a survey, Public Opinion Quarterly 56(4): 475-495. http:// dx.doi.org/10.1086/269338

Gruis, V.; Elsinga, M.; Wolters, A.; Priemus, H. 2005. Tenant empowerment through innovative tenures: an analysis of Woonbron Maasoevers' client choice programme, Housing Studies 20(1): 127-147. http:// dx.doi.org/10.1080/0267303042000308769

Hamzah, N.; Ramly, A.; Salleh, H.; Tawil, N. M.; Khoiry, M. A.; Che Ani, A. I. 2011. The importance of design process in housing quality, Procedia Engineering 20: 483-489. http://dx.doi.org/10.1016/j.proeng.2011.11.191

Hastings, E. M.; Wong, S. K.; Walters, M. 2006. Governance in a co-ownership environment: the management of multiple-ownership property in Hong Kong, Property Management 24(3): 293-308. http://dx.doi. org/10.1108/02637470610660165

Hills, S.; Worthing, D. 2006. Private home, public cultural asset: the maintenance behaviour of listed building owner-occupiers, Journal of Housing and Built Environment 21: 203-213. http://dx.doi.org/10.1007/ s10901-006-9043-8

Ho, D. C. W.; Yau, Y.; Wong, S. K.; Cheung, A. K. C.; Chau, K. W.; Leung, H. F. 2006. The effects of building management regimes on building performance in Hong Kong, Property Management 24(3): 309-321. http://dx.doi.org/10.1108/02637470610660174

Hui, E. Y. Y. 2005. Key success factors of building management in large and dense residential estates, Facilities 23(1/2): 47-62. http://dx.doi. org/10.1108/02632770510575893

Jiboye, A. D. 2011. Evaluating public housing performance: providing a basis for residential quality improvement in Nigeria, Middle-East Journal of Scientific Research 9(2): 225-232.

Kangwa, J.; Olubodun, F. 2003. An investigation into home owner maintenance awareness, management and skill-knowledge enhancing attributes, Structural Survey 21(2): 70-78. http://dx.doi. org/10.1108/02630800310479061

Kangwa, J.; Olubodun, F. 2006. Triggernomic Repair Process Analysis (TRAP): a methodology for better diagnosis of housing defects in the owner-occupier sector, Structural Survey 24(2): 127-137. http:// dx.doi.org/10.1108/02630800610666664

Kangwa, J.; Olubodun, F. 2007. Improvement-led home maintenance strategies and quality expectations: the significance of owner-occupiers' prior knowledge of house defects on upkeep decisions, Structural Survey 25(1): 39-50. http://dx.doi. org/10.1108/02630800710740967

Kelly, J. M. 2003. Citizen satisfaction and administrative performance measures: is there really a link?, Urban Affairs Review 38(6): 855-866. http://dx.doi. org/10.1177/1078087403038006005

Krosnick, J. A.; Fabrigar, L. R. 1997. Designing rating scales for effective measurement in surveys, in L. Lyberg, M. Collins, L. Decker, E. Deleeuw, D. Dippo,
N. Schwarz, D. Trewing (Eds.). Survey measurement and process quality. New York: Wiley-Interscience, 141-164.

Lai, A. W.; Pang, P. S. 2010. Measuring performance for building maintenance providers, Journal of Construction Engineering and Management 136(8): 864-876. http://dx.doi.org/10.1061/(ASCE)CO.19437862.0000191

Lam, T. Y. 2008. Procuring professional housing maintenance services, Facilities 26(1/2): 33-53. http://dx.doi. org/10.1108/02632770810840291

Lee, R.; Wordsworth, P. 2001. Lee’s building maintenance management. 4th ed. Oxford: Blackwell Science.

Li, L.; Ni, J. 2009. Short-term decision support system for maintenance task prioritization, International Journal of Production Economics 121: 195-202. http://dx.doi.org/10.1016/j.ijpe.2009.05.006

Low, S. P.; Peh, K. W. 1996. A framework for implementing TQM in construction, The TQM Magazine 8(5): 39-46. http://dx.doi.org/10.1108/09544789610146033

Lujanen, M. 2010. Legal challenges in ensuring regular maintenance and repairs of owner occupied apartment blocks, International Journal of Law in the Built Environment 2(2): 178-197. http://dx.doi. org/10.1108/17561451011058807

Mossel, H. J.; Jansen, S. J. 2010. Maintenance services in social housing: what do residents find important?, Structural Survey 28(3): 215-229. http://dx.doi. org/10.1108/02630801011058942

Mossel, H. J.; Straub, A. 2009. The need for customizing maintenance services in social housing, Construction Management and Economics 27(2): 135-151. http:// dx.doi.org/10.1080/01446190802695766

Narayan, V. 2003. Effective maintenance management: risk and reliability strategies for optimizing performance. New York: Industrial Press.

Oladapo, A. A. 2006. A study of tenants' maintenance awareness, responsibility and satisfaction in institutional housing in Nigeria, International Journal of Strategic Property Management 10(4): 217-231.

Oyedele, L. O.; Tham, K.W. 2007. Clients' assessment of architects' performance in building delivery process: evidence from Nigeria, Building and Environment 42(5): 2090-2099. http://dx.doi.org/10.1016/j.buildenv.2005.06.030

Pallant, J. 2010. SPSS survival manual: a step by step guide to data analysis using SPSS. 4th ed. Berkshire: Open University Press.

Perng, Y.-H.; Hsia, Y.-P.; Lu, H.-J. 2007. A service quality improvement dynamic decision support system for refurbishment contractors, Total Quality Management \& Business Excellence 18(7): 731-749. http:// dx.doi.org/10.1080/14783360701349716

Pintelon, L.; Puyvelde, F. V. 1997. Maintenance performance reporting systems: some experiences, Journal of Quality in Maintenance Engineering 3(1): 4-15. http://dx.doi.org/10.1108/13552519710161508

Ryu, E.; Couper, M. P.; Marans, R. W. 2005. Survey incentives: cash vs. in-kind; face-to-face vs. mail; response rate vs. nonresponse error, International Journal of Public Opinion Research 18(1): 89-106. http://dx.doi.org/10.1093/ijpor/edh089 
Siegert, N. V. 2004. What to do with public rental housing?: challenges and option. Washington DC: InterAmerican Development Bank.

Siu, G. K.; Bridge, A.; Skitmore, M. 2001. Assessing the service quality of building maintenance providers: mechanical and engineering services, Construction Management and Economics 19(7): 719-726. http:// dx.doi.org/10.1080/01446190110062104

Stewart, J.; Clayton, J.; Ruston, A. 2006. Encouraging and enabling low-income owner-occupiers to maintain their homes: an exploratory study, Property Management 24(5): 449-463. http://dx.doi. org/10.1108/02637470610710510

Straub, A. 2009. Cost savings from performance-based maintenance contracting, International Journal of Strategic Property Management 13(3): 205-217. http://dx.doi.org/10.3846/1648-715X.2009.13.205-217

Streiner, L. D.; Norman, G. R. 2008. Health measurement scales: a practical guide to their development and use. New York, NY, USA: Oxford University Press. http://dx.doi.org/10.1093/acprof:o so/9780199231881.001.0001

Turner, J. R.; Müller, R. 2004. Communication and cooperation on projects between the project owner as principal and the project manager as agent, European Management Journal 22(3): 327-336. http:// dx.doi.org/10.1016/j.emj.2004.04.010

Van de Ven, A.; Ferry, D. 1979. Measuring and assessing organizations. New York: Wiley.

Wilhelmsson, M. 2008. House price depreciation rates and level of maintenance, Journal of Housing Economics 17(1): 88-101. http://dx.doi.org/10.1016/j. jhe.2007.09.001

Williams, C. S.; Saunders, M. N. K.; Staughton, R. V. W. 1999. Understanding service quality in the new public sector: an exploration of relationships in the process of funding social housing, International Journal of Public Sector Management 12(4) 366-380. http:// dx.doi.org/10.1108/09513559910282858
Yasamis, F.; Arditi, D.; Mohammadi, J. 2002. Assessing contractor quality performance, Construction Management and Economics 20(3): 211-223. http://dx.doi. org/10.1080/01446190110113693

Yau, Y. 2010. Engaging homeowners in building care in Hong Kong: drivers and barriers, Journal of Building Appraisal 6: 35-48. http://dx.doi.org/10.1057/ jba.2010.6

Yau, Y. 2011a. Homeowners' participation in management of multi-storey residential buildings: the Hong Kong's case, Property Management 29(4): 345-356. http://dx.doi.org/10.1108/02637471111154791

Yau, Y. 2011b. Collectivism and activism in housing management in Hong Kong, Habitat International 35(2): 327-334. http://dx.doi.org/10.1016/j.habitatint.2010.11.006

Yau, Y. 2013. Willingness to participate in collective action: the case of multiowned housing management, Journal of Urban Affairs 35(2): 153-171. http:// dx.doi.org/10.1111/j.1467-9906.2012.00621.x

Yau, Y.; Ho, D. C. W. 2009. The effects of building management practices on residential property prices in Hong Kong, Journal of Building Appraisal 4(3): 157167. http://dx.doi.org/10.1057/jba.2008.42

Yip, N. M. 2001. Tenant participation and the management of public housing - The Estate Management Advisory Committee of Hong Kong, Property Management 19(1): 10-18. http://dx.doi. org/10.1108/02637470110366176

Zagorsky, J. L.; Rhoton, P. 2008. The effects of promised monetary incentives on attrition in a long-term panel survey, Public Opinion Quarterly 72(3): 502-513. http://dx.doi.org/10.1093/poq/nfn025

Zavadskas, E. K.; Vilutienè, T. (2006). A multiple criteria evaluation of multi-family apartment block's maintenance contractors: I-Model for maintenance contractor evaluation and the determination of its selection criteria, Building and Environment 41(5): 621-632. http://dx.doi.org/10.1016/j.buildenv.2005.02.019 